\title{
Association between histological findings, aminotransferase levels and viral genotype in chronic hepatitis $\mathbf{C}$ infection
}

\author{
Amanda Alves Fecury ${ }^{[1]}$, Marcella Kelly Costa de Almeida ${ }^{[1]}$, Kemper Nunes dos Santos ${ }^{[1]}$, \\ Andrei da Silva Freitas ${ }^{[1]}$, Socorro de Fátima Loureiro Dantas ${ }^{[1]}$, Carlos Araújo da Costa ${ }^{[1]}$, \\ Ângelo Barlleta Crescente ${ }^{[1]}$, Rita Catarina Medeiros de Sousa ${ }^{[1]}$, Elza Baía de Brito ${ }^{[1]}$, \\ Reza Nassiri ${ }^{[2]}$, Elizabeth Lampe ${ }^{[3]}$ and Luisa Caricio Martins ${ }^{[1]}$
}

[1]. Laboratório de Patologia Clínica das Doenças Tropicais, Núcleo de Medicina Tropical, Universidade Federal do Pará, Belém, PA. [2]. Institute of International Health, Michigan State University, Michigan, USA. [3]. Fundação Oswaldo Cruz, Rio de Janeiro, RJ.

\begin{abstract}
Introduction: The genomic heterogeneity of hepatitis $\mathrm{C}$ virus (HCV) influences liver disorders. This study aimed to determine the prevalence of HCV genotypes and to investigate the influence of these genotypes on disease progression. Methods: Blood samples and liver biopsies were collected from HCV-seropositive patients for serological analysis, biochemical marker measurements, HCV genotyping and histopathological evaluation. Results: Hepatitis C virus-ribonucleic acid (HCV-RNA) was detected in 107 patients $(90.6 \%$ with genotype 1 and $9.4 \%$ with genotype 3$)$. Patients infected with genotype 1 exhibited higher mean necroinflammatory activity and fibrosis. Conclusions: HCV genotype 1 was the most prevalent and was associated with greater liver dysfunction.
\end{abstract}

Keywords: Hepatitis C virus. Genotype. Histopathology.

Hepatitis $\mathrm{C}$ virus (HCV) infection is often asymptomatic, but it is chronic in a large (85\%) proportion of cases. Approximately $20 \%$ of individuals with chronic HCV develop liver damage, cirrhosis or cancer ${ }^{1}$.

In Brazil, the seroprevalence of HCV is moderate, although rates vary among different regions of the country ${ }^{2}$. Genotype 1 is predominant, followed by genotypes 3 and $2^{3}$. In the State of Pará, the overall prevalence ranges from 0.5 to $2 \%$ among blood donor candidates ${ }^{4}$, and the genotype distribution is similar to that reported elsewhere in Brazil ${ }^{5}$.

Hepatitis $\mathrm{C}$ virus genotype 1 has been associated with severe liver damage and the response to treatment ${ }^{6}$. However, other studies were unable to confirm this association ${ }^{7}$. Brazilian studies correlating the different $\mathrm{HCV}$ genotypes with histological and clinical presentation are scarce and have not confirmed an association between liver disease severity and $\mathrm{HCV}$ genotype ${ }^{8,9}$.

The objectives of this study were to determine the prevalence of $\mathrm{HCV}$ genotypes in patients with chronic hepatitis $\mathrm{C}$ in the State of Pará, Brazil and to investigate the influence of these genotypes on the biochemical and histopathological parameters of the disease.

Address to: Dra ${ }^{\mathrm{a}}$ Luisa Caricio Martins. Laboratório de Patologia Clínica das Doenças Tropicais/NMT/UFPA. Av. Generalíssimo Deodoro 92, Umarizal, 66055-240 Belém, PA, Brasil.

Phone: 5591 3201-6812

e-mail: caricio@ufpa.br

Received 19 September 2012

Accepted 27 March 2013
A total of 152 adult patients of both genders with positive HCV serology participated between 2008 and 2010. None of the patients was co-infected with hepatitis B virus (HBV) or human immunodeficiency virus (HIV). The study was approved by the Ethics Committee on Human Research of the Núcleo de Medicina Tropical.

Peripheral blood was collected from each patient for enzyme immunoassays, the measurement of biochemical markers of liver damage and the investigation of viral ribonucleic acid (RNA) and HCV genotyping by molecular biology techniques. The ETIAB-HCVK-4 (DiaSorin, Italy) enzyme-linked immunosorbent assay (ELISA) kit was used to detect specific HCV antibodies.

RNA was extracted from all samples using the QIAamp Viral RNA kit (Qiagen, Germany). HCV-RNA was detected in the sera of the patients by nested polymerase chain reaction $(\mathrm{PCR})^{10}$. Viral genotypes were determined by the restriction fragment length polymorphism (RFLP) technique using the restriction enzymes Ava II and Afa I ${ }^{11}$.

Alanine transaminase (ALT), aspartate transaminase (AST) and gamma-glutamyl transpeptidase $(\gamma$-GT) were measured using appropriate kits and an automated analyzer (Katal, Minas Gerais, Brazil).

Liver biopsies were obtained from 107 patients who tested positive for viral RNA. The biopsies were cut and stained with hematoxylin-eosin and analyzed by a pathologist. The fibrosis stage and inflammatory activity grade were used to diagnose chronic hepatitis ${ }^{12}$.

The log-likelihood ratio G-test ${ }^{13}$ was used to compare frequencies and to evaluate the association between genders and age groups. 
Differences between histological activity ( 0 to 3 ) and stage of fibrosis ( 0 or 1 ) were evaluated by the Mann-Whitney test.

Statistical analysis was performed using the BioEstat 5.0 program (available at http://www.mamiraua.org.br/downloads/ programas), with the level of significance set at $5 \%$.

Viral RNA was detected in 107 (70.4\%) of 152 patients. In the remaining $45(29.6 \%)$ patients, the viral load could not be detected by the implemented method, likely because it was very low. In total, $97(90.6 \%)$ of the 107 patients were infected with genotype 1 , and $10(9.4 \%)$ were infected with genotype 3 . There was no case of mixed infection. No difference in gender distribution or age was observed between the HCV genotypes. The mean age was 45 years.

Liver biopsies were obtained from all 107 patients from whom viral RNA had been isolated, and all samples were submitted to histopathological examination, which revealed chronic hepatitis. Grade 0 or 1 necroinflammatory activity was observed in 33\% $(35 / 107)$ of these patients, and grade 2 or 3 inflammation was noted in $67 \%(72 / 107)$. Meanwhile, $40 \%(43 / 107)$ of patients had stage 0 or 1 fibrosis, and $60 \%(64 / 107)$ had stage 2 to 4 (Table 1). An analysis of the histopathological alterations according to viral genotype using the Mann-Whitney test showed higher mean necroinflammatory activity and a higher degree of fibrosis among patients infected with genotype 1 (Table 1).

No significant association was observed between the biochemical markers studied (transaminases, $\gamma-\mathrm{GT}$ ) and the different genotypes. There was also no association between these markers and histological activity or stage of fibrosis.

The present results showed a high prevalence of HCV genotype $1(90 \%)$, followed by genotype $3(10 \%)$. Genotypes 2 ,
4, 5 and 6 were not detected. Other studies conducted in northern Brazil reported a similar distribution ${ }^{3}$. This finding might be explained by the historic colonization of Pará by Europeans, Africans and Asians. Genotype 1 is the most prevalent in those regions, followed by genotype $3^{14}$.

The mean age of the patients in the present cohort was 45 years, a finding consistent with those of other studies conducted in $\mathrm{Brazil}^{8}$. No difference in age was observed between patients infected with genotypes 1 and 3. Similar age profiles have been reported in patients in Piauí, Brazil9.

This study demonstrated an association between histopathological alterations and HCV genotype. The present findings indicate a significant risk of high-grade liver fibrosis and histological activity in patients infected with genotype 1 . Similar results have been reported in studies conducted in other countries ${ }^{6,7}$.

In general, chronic hepatitis $\mathrm{C}$ patients with elevated ALT levels and high serum HCV-RNA titers are considered to have active $\mathrm{HCV}$ replication in the liver and a predisposition to liver injury. In addition, serum ALT is currently used as a marker for the degree of histological damage. However, studies have reported equivocal results regarding the association between the degree of histological damage, serum ALT level, HCV-RNA titer and $\mathrm{HCV}$ genotype in chronic hepatitis $\mathrm{C}^{15}$. The present study showed no significant correlation between serum ALT, AST or $\gamma$-GT levels and histological abnormalities.

In conclusion, the present study confirms previous reports that showed a high prevalence of genotype 1 in the State of Pará and demonstrates that this genotype is associated with more severe histological alterations. These findings also suggest that alterations in biochemical parameters may not be good markers for the extent of liver damage.

TABLE 1 - Association between hepatitis C virus genotypes 1 and 3 and histopathological findings in the liver.

\begin{tabular}{|c|c|c|c|c|c|}
\hline \multirow[b]{2}{*}{ Histopathological finding } & \multicolumn{2}{|c|}{ Genotype 1} & \multicolumn{2}{|c|}{ Genotype 3} & \multirow[b]{2}{*}{$\mathrm{P}$ value } \\
\hline & $\mathrm{n}$ & $\%$ & $\mathrm{n}$ & $\%$ & \\
\hline \multicolumn{6}{|l|}{ Histological activity } \\
\hline 0 & 4 & 4.0 & 1 & 10.0 & \\
\hline 1 & 24 & 25.0 & 6 & 60.0 & \\
\hline mean $\pm \mathrm{SD}$ & \multicolumn{2}{|c|}{$2 \pm 0.71$} & \multicolumn{2}{|c|}{$1 \pm 0.82$} & 0.0483 \\
\hline \multicolumn{6}{|l|}{ Stage of fibrosis } \\
\hline 0 & 6 & 6.0 & 1 & 10.0 & \\
\hline 4 & 1 & 1.0 & - & & \\
\hline mean $\pm \mathrm{SD}$ & \multicolumn{2}{|c|}{$2 \pm 0.80$} & \multicolumn{2}{|c|}{$1 \pm 0.78$} & 0.0431 \\
\hline
\end{tabular}

SD: Standard deviation. 


\section{CONFLICT OF INTEREST}

The authors declare that there is no conflict of interest.

\section{FINANCIAL SUPPORT}

Departamento de Ciência e Tecnologia/Ministério da Saúde (DECIT/MS) and Fundação de Amparo à Pesquisa do Estado do Pará (FAPESPA); Grant 035/2007.

\section{REFERENCES}

1. Aguilera GA, Romero YS, Regueiro BJ. Epidemiology and clinical manifestations of viral hepatitis. Enferm Infecc Microbiol Clin 2006; 24:264-276.

2. Ministério da Saúde. Secretaria de Vigilância em Saúde, Departamento de Vigilância Epidemiológica. Hepatites virais: o Brasil está atento. Brasília, DF: Ministério da Saúde; 2008.

3. Campiotto S, Pinho JR, Carrilho FJ, Silva LC, Souto FJ, Spinelli V, et al. Geographic distribution of hepatitis $\mathrm{C}$ virus genotypes in Brazil. Braz J Med Biol Res 2005; 38:41-49.

4. Fonseca JCF, Brasil LM. Hepatitis C virus infection in the Brazilian Amazon region. Rev Soc Bras Med Trop 2004; 37:S1-S8.

5. Sawada L, Pinheiro AC, Locks D, Pimenta AS, Rezende PR, Crespo DM, et al. Distribution of hepatitis $C$ virus genotypes among different exposure categories in the State of Pará, Brazilian Amazon. Rev Soc Bras Med Trop 2011; 44:8-12.
6. Singh S, Gupta R, Malhotra V, Sarin SK. Predictors of histological activity and fibrosis in chronic hepatitis $\mathrm{C}$ infection: a study from North India. Ind J Pathol Microbiol 2010; 53:238-243.

7. Lee YS, Yoon SK, Chung ES, Bae SH, Choi JY, Han JY, et al. The relationship of histologic activity to serum ALT, HCV genotype and HCV RNA titers in chronic hepatitis C. J Korean Med Sci 2001; 16:585-591.

8. Codes L, Freitas LA, Santos-Jesus R, Vivitski L, Silva LK, Trepo C, et al. Comparative study of hepatitis $\mathrm{C}$ virus genotypes 1 and 3 in Salvador, Bahia Brazil. Braz J Infect Dis 2003; 7:409-417.

9. Veras KN, Jacobina KS, Soares VY, Avelino MA, Vasconcelos CM, Parente JM. Chronic hepatitis C virus in the state of Piauí, northeastern Brazil. Braz J Infect Dis 2009; 13:125-129.

10. Oliveira JM, Rispeter K, Viazov S, Saback FL, Roggendorf M, Yoshida CFT. Differences in HCV antibody patterns in haemodialysis patients infected with the same virus isolate. J Med Virol 2001; 63:265-270.

11. Hazari S, Acharya SK, Panda SK. Development and evolution of qualitative comparative reverse transcription polymerase chain reaction (RT-PCR) for hepatitis C virus RNA in serum using transcribed thio-RNA as internal control. J Virol Methods 2004; 116:45-54.

12. Gayotto LCC, Comitê SBP/SBH. Visão histórica e consenso nacional sobre a classificação das hepatites crônicas. Gastroenterol Endosc Digest 2000; 19:137-140

13. Sokal RR, Rohlf FJ. Biometry: the principles and practice of statistics in biological research. $4^{\text {th }}$ edition. New York: Freeman \& Company; 2011.

14. Esteban JI, Sauleda S, Quer J. The changing epidemiology of hepatitis C virus infection in Europe (Review). J Hepatol 2008; 48:148-162.

15. Naito M, Hayashi N, Hagiwara H, Hiramatsu N, Kasahara A, Fusamoto H, et al. Serum hepatitis C virus RNA quantity and histological features of hepatitis C virus carriers with persistently normal ALT levels. Hepatol 1994; 19:871-875. 